\title{
Contamination of Nitrate In Groundwater of Amravati Region
}

\author{
VivekRaut $^{1}$, Prof. Dilendra Jasutkar ${ }^{2}$ \\ Department of Environmental Engineering, Nuva College of Engineering \& Technology, Nagpur.
}

DOI: 10.46335/IJIES.2020.5.11.5

\begin{abstract}
Groundwater is an important natural resources with high economic value and social significance. It supplies almost half of all drinking water in the world (WWAP, 2009) and plays a key role in food production all over the world. Nitrate (NO3-) is one of the main groundwater pollutant. Nirate treats depends on scale which can be take on acute and chronic forms.Consuming water containing high nirate concentration can have almost immediate effect on a person and could cause the risk of various diseases one of which is "Methemoglobinemia" in which blood lacks the ability to carry sufficient oxygen to the individual body cells. As difference in concentration of nitrates in water has made it important to study the contamination so that proper parameters or undesirable effect of nitrate can be studied. In rural areas, groundwater contamination by nitrates is a problem related to the spreading of organic and chemical fertilizers by farmers and, to some extent, to effluents from domestic sewage systems. Health effects of groundwater contamination by nitrates have been assessed several times and may lead to important consequences for infants. Usually groundwater cannot be controlled so it become very difficult to study the variation in parameters. However, several reportsshows that there is an increase in groundwater contamination because of Nitrates.
\end{abstract}

Keywords- Nitrates,Methemoglobinemia,Groundwater

\section{I- INTRODUCTION}

$\mathbf{N}$ trate is the most common chemical contaminant in the world's groundwater aquifers. Nitrate is a colorless, odorless, and tasteless compound that is present in groundwater. Nitrate is present widespread in the environment and the major sources of nitrate pollution in both developed and developing countries is crop fertilization (Gatseva et al., 2008). Common sources of nitrate include: Fertilizers and manure, animal feedlots, wastewater-disposal, industrial waste, and food processing waste, septic systems, and $\mathrm{N}$-fixation from atmosphere by legumes, bacteria and lightning (Smith et al., 2005). Nitrate and nitrite have some hazards for human. Most important environmental problems caused by nitrate are eutrophication in water supplies and infectious disease (Loganathan et al., 2013) Toxic nitrate has a negative effect on the human's health, which could result in many diseases, such as birth defects, spontaneous abortion, increased infant mortality, diarrhea, abdominal pain, vomiting, diabetes, hypertension, respiratory tract infections, changes in the immune system, and methemoglobinemia (Azizullah et al., 2011; Ward et al ., 2011). The aim of the present study was thus to determine the concentrations of nitrate and in ground water sources of Amaravati region and to compare the nitrate and contents with standards levels because there is no whole information available on nitrate in ground water sources.

\subsection{About the Amravati region}

Amravati District is one of the eleven districts of Vidarbha region of Maharashtra State. It is situated in the northern part of the State abutting Madhya Pradesh State and lies between north latitudes $20^{\circ} 32^{\prime}$ and $21^{\circ} 46^{\prime}$ and east longitudes $76^{\circ} 37^{\prime}$ and $78^{\circ} 27^{\prime}$. The total area of 
the district is $12210 \mathrm{sq} . \mathrm{km}$. and falls in Survey of India degree sheets $55 \mathrm{G}, 55 \mathrm{H}, 55 \mathrm{~K}$ and $55 \mathrm{~L}$. The district is bounded on the north by Madhya Pradesh, on the east by Nagpur and Wardha districts, and on the south and south west by Yavatmal, Akola and Buldhana districts. Wardha River forms the eastern boundary of the district.

\section{II- MATERIAL AND METHODOLOGY}

2.1 MPCB monitors ground water quality for parameters like $\mathrm{pH}$, total hardness, Calcium, Magnesium, Chloride, total dissolved solids, Fluoride, Manganese, Nitrate, Sulphates and so on once in six months. Based on the stringency of the parameters and its relative importance in the overall quality of water for drinking purposes each parameter has been assigned specific weightage. The relative weights of the same have been determined for the parameters monitored and recorded by MPCB for the water samples monitored.These weights indicate the relative harmfulness when present in water. The maximum weight assigned is 5 and minimum is 1 .

Table No. 11: Groundwater classification based on the Water Quality Index

\begin{tabular}{|l|l|l|}
\hline WQI Value & \multicolumn{1}{|c|}{ Water Quality } & $\begin{array}{c}\text { Colour code } \\
\text { used in this } \\
\text { report }\end{array}$ \\
\hline$<50$ & Excellent & \\
\hline $50-100$ & Good water & \\
\hline $100-200$ & Poor Water & \\
\hline $200-300$ & Very Very Poor water & \\
\hline$>300$ & $\begin{array}{l}\text { Water Unsuitable for } \\
\text { drinking }\end{array}$ & \\
\hline
\end{tabular}

2.2 Sample Collection, Preservation And Storage

- Samples should be collected in plastic or glass bottles. All bottles must be thoroughly cleaned and rinsed with reagent water. Volume collected should be sufficient to insure a representative sample, allow for replicate analysis (if required), and minimize waste disposal.

- $\quad$ Samples must be preserved with $\mathrm{H} 2 \mathrm{SO} 4$ to a $\mathrm{pH}$ $<2$ and cooled to $4^{\circ} \mathrm{C}$ at the time of collection.

- Samples should be analyzed as soon as possible after collection. If storage is required, preserved samples are maintained at $4^{\circ} \mathrm{C}$ and may be held for up to 28 days.

- $\quad$ Samples to be analyzed for nitrate or nitrite only should be cooled to $4^{\circ} \mathrm{C}$ and analyzed within 48 hours.

\subsection{Analytic Measurements}

Nitrate and nitrite were measured using a Spectrophotometer $2100 \mathrm{UV}-\mathrm{Vis}$, at 549 and $410 \mathrm{~nm}$ according to the standard methods for the examination of water and wastewater (APHA, AWWA, WPCF 1992). The SPSS software was used for statistical analysis with a significance determined at $\mathrm{p}<0.05$.

\section{III- RESULTS AND DISCUSSION}

3.1. Nitrate contamination of different Taluka's of Amravati reagion

From the table given below we find out that groundwater reading of $\mathrm{NO}_{3}$. The reading where taken in three parts and the reading given below is average of the three reading taken from the different taluka's of the Amravati region.The reading of the following samples were taken as per the process describe in chap. 3 methdology and the experiment was carried out at college laboratry.

Table No. Readings of Nitrate from different taluka of Amravati

\begin{tabular}{|c|c|c|}
\hline $\begin{array}{c}\text { Sr } \\
\text { No }\end{array}$ & Taluka & $\begin{array}{c}\text { Average } \\
\text { Reading }\left(\mathbf{N O}_{\mathbf{3}}\right)\end{array}$ \\
\hline 1 & NandgaonKhandeswar & 63.34 \\
\hline 2 & Tiwasa & 68 \\
\hline 3 & Chandur Railway & 62 \\
\hline 4 & Bhatkali & 49.33 \\
\hline 5 & Morshi & 49.67 \\
\hline 6 & Achalpur & 39.67 \\
\hline
\end{tabular}

3.2 Nitrate contamination in different villages of the above Taluka's

\begin{tabular}{|c|l|l|}
\hline Sr No. & Village Name & $\begin{array}{l}\text { Avg. Reading } \\
\text { of } \mathrm{NO}_{3}\end{array}$ \\
\hline 1 & Maulichor & 68 \\
\hline 2 & Hiwaramurade & 62 \\
\hline 3 & Bharwadi & 70 \\
\hline 4 & Anjangaon & 72 \\
\hline 5 & Asegaon & 59 \\
\hline 6 & AmlaVishvesheir & 61 \\
\hline 7 & Dapori & 53 \\
\hline 8 & pardi & 52 \\
\hline 9 & Chaasala & 43 \\
\hline 10 & Pathrot & 42 \\
\hline
\end{tabular}




\section{IV- CONCLUSION}

Groundwater contamination by nitrate is a widespread problem in our India. By affecting the groundwater quality it can cause public health problems, and environmental degradation of ecosystems. All these negative effects can be minimized by proper groundwater management and good governance to mitigate the risks for nitrate contamination. However, in order to better manage nitrate contamination in groundwater systems, researchers, water resources specialists and policy makers do need information on the scope, distribution and severity of groundwater nitrate contamination. In other words, it would be better to facilitate early diagnosis of possible changes and widen their inspiration for selecting effective measures for interventions.

\section{REFERENCES}

[1] Fiore, J., and O'Brien, J.E., "Automation in Sanitary Chemistry - Parts 1 \& 2:

[2] Determination of Nitrates and Nitrites", Wastes Engineering 33, 128 \&238 (1962).

[3] Armstrong, F.A., Stearns, C.R., and Strickland, J.D., "The Measurement of Upwelling and Subsequent Biological Processes by Means of the TechniconAutoAnalyzer and Associated Equipment", Deep Sea Research 14, pp. 381-389 (1967).

[4] Annual Book of ASTM Standards, Part 31, "Water", Standard D1254, p. 366 (1976).

[5] Standard Methods for the Examination of Water and Wastewater, 17th Edition, pp. 4-91, Method 4500-NO3 F (1992).

[6] Chemical Analyses for Water Quality Manual, Department of the Interior, FWPCA, R.A. Taft Engineering Center Training Program, Cincinnati, Ohio 45226 (January, 1966).

[7] Nitrate and Nitrite: Agency for Toxic Substances and Disease Registry.2011, CAS ID: 84145-82-4.

[8] Barros , R.; Isidoro, D.; Aragues, R. Irrigation management, nitrogen fertilization and nitrogen losses in the return flows of La Violada irrigation district (Spain). AgrEcosyst Environ., 2012 155,161 171.

[9] Rojas Fabro , A.Y.; Pacheco Avila , J.G.; EstellerAlberich, M.V.; Cabrera Sansores, S.A.; CamargoValero, M.A. Spatial distribution of nitrate health risk associated with groundwater use as drinking water in Merida, Mexico. ApplGeogr, 2015, 65, 4957. doi:10.1016/j.

[10] Singh, K.P.; Singh, V.K.; Malik, A.;Basant, N. Distribution of nitrogen species in groundwater aquifers of an industrial area in alluvial Indo-Gangetic plains: a case study. Environ Geochem Health, 2006, 28, 473485.

[11] Thorburn, P.J.; Jiggs, J.S.; Weier, K.L.; Keating, B.A. Nitrate in groundwater of intensive agricultural areas in coastal Northeastern Australia. AgrEcosys Environ, 2003, 94, 4958.

[12] Daniela Ducci. An Easy-to-Use Method for Assessing Nitrate Contamination Susceptibility in Groundwater.Geofluids, 2018, Article ID 1371825, 12pages, https://doi.org/10.1155/2018/1371825.

[13] Liu, J.; Jiang ,L.H.; Zhang, C.J.; Li,P.; Zhao. T.K. Nitrate-nitrogen contamination in groundwater: Spatiotemporal variation and driving factors undercropland in Shandong Province, China.3rd IOP Conf. Ser.: Earth Environ. Sci.82 012059,2017,82.

[14] Evans, T.A.; Maidment, D.R.A spatial and statistical assessment of the vulnerability of Texas groundwater to nitrate contamination.CRWR online report $95 e 2$. Centre for Research in Water Resources, The University of Texas at Austin. 1995. [

[15] Marinov, I.; Marinov, A.M.A coupled mathematical model to predict the influence of nitrogen fertilization on crop, soil and groundwater quality. Water Resource Manag, 2014, 28, 52315246.

[16] Suthar, S.; Bishnoi, P.; Singh, S.; Mutiyar, P.K.; Nema, A.K.; Patil, N.S. Nitrate contamination in groundwater of some rural areas of Rajasthan, India. J Hazard Mater, 2009, 171, 189199.

[17] D.K Todd, (1980).Groundwater Hydrology John Wiley \&SOns PTE LTD

[18] W.H.O (2007). Nitrate and nitrite in drinkingwater Background document for development of WHO Guidelines for Drinking-water Quality, WHO/SDE/WSH/07.01/16.

[19] J.A. Delgado, (2002). Quantifying the loss mechanisms of nitrogen. Journal of Soil and Water Conservation, 57, 389-398.

[20] I.R. Lake, A.A. Lovett, K.M. Hiscock, M. Betson, A. Foley, G. Sünnenberg, (2003).Evaluating factors influencing groundwater vulnerability to nitrate pollution: developing the potential of GIS. Journal of Environmental Management, 68, 315-328.

[21] J. J. Schroder, D. Scholefield, F. Cabral, \& G. Hofman, (2004). The effects of nutrient losses from agriculture on ground and surface water quality: the position of science in developing

[22] indicators for regulation. Environmental Science and Policy, 7, 15-23.

[23] S.J. Birkinshaw, \& J. Ewen, (2000). Nitrogen transformation component for SHETRAN catchment nitrate transport modeling. Journal of Hydrology, 230, 1-1

[24] Saadi, Maslouhi, (2003). Modeling nitrogen dynamics in unsaturated soils for evaluating nitrate contamination of the Mnasra groundwater. Advances in Environmental Research, 7, 803-823. 
[25] V.M. Chowdary, N.H. Rao, \& P.B.S. Sarma, (2005).Decision support framework for assessment of non-point-source pollution of groundwater in large irrigation projects. Agricultural Water Management, 75, 194-225.

[26] M. D. Hall, M. J. Shaffer, R. M. Waskom, \& J. A. Delgado, (2001). Regional nitrate leaching variability: what makes a difference in northeasternColorado. Journal of the American Water Resources Association, 37, 139-150

[27] US EPA, (2000).Drinking water standards and health advisories.U.S. Environmental Protection Agency, Office of Water.822-B00-001.

[28] M.N. Almasri, J. J. Kaluarachchi, (2004). Assessment and management of long-term nitrate pollution of ground water in agriculture-dominated watersheds. Journal of Hydrology, 295, 225-245.

[29] UNEP (2003).Desk study on the environment in the occupied Palestinian territories.Nairobi, Kenya: United Nations Environment Programme.

[30] D.Postma, C. Boesen, H. Kristiansen, \& F. Larsen, (1991). Nitrate reduction in an unconfined sandy aquifer; water chemistry, reduction processes, and geochemical modeling. Water Resources Research, 27, 2027-2045.

[31] T.M. Addiscott, A.P. Whitmore, \& D.S. Powlson, (1992).Farming fertilizers and the nitrate problems.Wallingford: CAB International, London.

[32] K.E. Schilling, C.F. Wolter, (2001), Contribution of base flow to nonpoint source pollution loads in an agricultural watershed. Ground Water, 39, 49-58.

[33] M.N. Almasri, \& J.J. Kaluarachchi, (2004).Assessment and management of long-term nitrate pollution of ground water in agriculture-dominated watersheds.Journal of Hydrology, 295. 